\title{
Relationship Between Corn Vitreousness and Ruminal In Situ Starch Degradability
}

\author{
C. E. S. Correa, ${ }^{*}$ R. D. Shaver, $\dagger^{, 1}$ M. N. Pereira, ${ }^{*}$ J. G. Lauer,,$^{, 2}$, and K. Kohn $\dagger^{, 2}$ \\ *Universidade Federal de Lavras, Departamento de Zootecnia, Lavras, Brazil, 37200-000 \\ †University of Wisconsin, Madison 53706
}

\begin{abstract}
The objective of this experiment was to determine the relationship between corn kernel vitreousness and ruminal in situ starch degradation. Fourteen U.S. and five Brazilian corn hybrids cultivated in their respective countries were evaluated. The U.S. dent hybrids were harvested at one-half milk line, black layer, and 21 $\mathrm{d}$ after black layer stages of maturity. Brazilian flint hybrids were harvested only at the latest stage of maturity. Vitreousness was determined by manual dissection of the kernels. Ruminal in situ degradation of starch was determined in three lactating Holstein cows fitted with ruminal cannulae. Vitreousness of the five mature Brazilian hybrids averaged $73.1 \%$ (range of $64.2 \%$ to $80.0 \%$ ), while vitreousness of the 14 mature U.S. hybrids averaged $48.2 \%$ (range of $34.9 \%$ to $62.3 \%$ ). Within the 14 U.S. hybrids, average vitreousness increased from $42.8 \%$ to $48.2 \%$ as stage of maturity progressed from one-half milk line to $21 \mathrm{~d}$ after black layer. The correlation between kernel density and vitreousness was 0.87 . The correlations between kernel vitreousness or density and ruminal starch availability were -0.93 and -0.87 , respectively. With advancing maturity, kernel vitreousness and density increased while ruminal starch availability decreased. Kernel vitreousness and density may be useful parameters for which to select corn hybrids for high ruminal starch availability. Density may be a more practical measurement than vitreousness for screening large corn data sets.
\end{abstract}

(Key words: corn, density, rumen, starch, vitreousness)

Abbreviation key: $\mathbf{B L}=$ black layer maturity stage, HVH = high vitreousness hybrid, LVH = low vitreousness hybrid, HM = half milk line maturity stage, $\mathbf{M T}$ $=$ mature stage.

Received: January 28, 2002.

Accepted: May 6, 2002.

Corresponding Author: R. D. Shaver; e-mail: rdshaver@facstaff. wisc.edu.

${ }^{1}$ Department of Dairy Science.

${ }^{2}$ Department of Agronomy.

\section{INTRODUCTION}

Silage or grain harvested from corn (Zea mays) are important energy sources for ruminants. Flint corn has a greater proportion of vitreous endosperm than dent corn (Philippeau et al., 1999). Philippeau and MichaletDoureau (1997) observed that increased kernel vitreousness was associated with decreased ruminal starch degradation. Increased kernel vitreousness may explain the reduction in total-tract starch digestibility observed for mature corn silage (Bal et al., 1997; Johnson et al., 2002), the variation in the starch digestibility response to kernel processing of corn silage (Bal et al., 2000b; Dhiman et al., 2000; Johnson et al., 2002), and differences between corn hybrids grown for silage production in ruminal (Bal et al., 2000c) and total-tract starch digestibility (Bal et al., 2000a; Johnson et al., 2002). Better understanding the relationship between kernel vitreousness and starch digestibility may allow for improved selection of corn hybrids for silage and grain production resulting in improvements in the utilization of corn-based diets by ruminants.

The objective of this experiment was to determine the relationship between kernel vitreousness and ruminal in situ starch degradation. Corn hybrids grown in Brazil are primarily flint-endosperm cultivars, while U.S. hybrids are primarily dent-endosperm cultivars. Corn samples collected from both countries were evaluated in this study to provide a data set with a wide range in kernel vitreousness.

\section{MATERIALS AND METHODS}

Fourteen U.S. (Pioneer 3936, 38P05, 37R71, 35R57, Pioneer Hi-Bred Int., Inc., Johnston, IA; Jung 2240, Jung Seed Co., Randolph, WI; Novartis N2555Bt, NK Brand, Basel, Switzerland; DS Stealth 1280, Dairyland Seed Co., West Bend, WI; Renk RK232, Renk Seed Co., Sun Prairie, WI; Dekalb DK440, Dekalb Genetics, St. Louis, MO; Lemke 3090, Lemke Seed Farms, Mequon, WI; Pfister 2025, Pfister, El Paso, IL; Cargill 4111, Cargill Seed, Minneapolis, MN; Garst 8707, Garst Seed Co., Slater, IA; Kaltenberg K7001, Kaltenberg Seed Co., Waunakee, WI), and five Brazilian (Zeneca Z8501, 
Z8452, Sementes Dow Agrosciences, Jardinópolis, Brazil; Agroceres AG1051, Sementes Agroceres, Uberlândia, Brazil; Agromen Agromen3100, Sementes Agromen Ltda, Orlândia, Brazil; Novartis Tork, Syngenta Seeds, Uberlândia, Brazil) commercially available corn hybrids were cultivated in their respective countries. The U.S. hybrids were predominantly dent-endosperm cultivars, while the Brazilian hybrids were flint or predominantly-flint endosperm cultivars. The 2000 production year for the U.S. hybrids at the University of Wisconsin Arlington Agricultural Research Station in Arlington, WI was above average for precipitation due to late May-early June rainfall, which caused cool soil temperatures during this time period, above normal accumulation of growing degree units across the growing season, and normal for fall frost date. Production of the Brazilian hybrids was during the 1999-2000 growing season in southern Minas Gerais state; average temperature and precipitation were normal for that region. Starting at the early-dent stage of maturity, the middle portion of nine ears of the U.S. hybrids was evaluated twice a week and harvested at three maturity stages; one-half milk line (HM), black layer (BL), and $21 \mathrm{~d}$ after BL (mature; MT). Age at harvest was defined by the number of days in the interval between the planting date and harvest date. Kernels were frozen, shelled while frozen, and dried at $60^{\circ} \mathrm{C}$ for 48 hours. Kernel $\mathrm{DM}$ contents (mean $\pm \mathrm{SD}$ ) were: $62.0 \% \pm 1.2,74.3 \% \pm$ 2.7 , and $87.1 \% \pm 2.9$ for $\mathrm{HM}, \mathrm{BL}$, and $\mathrm{MT}$, respectively. Brazilian hybrids were harvested only at the mature stage of growth; kernel DM content was $92.0 \% \pm 1.6$.

Kernel density was determined using a pycnometer with a removable cap that allowed whole kernel inclusion. The cap was adjusted to maintain a constant internal volume. A known weight pycnometer was filled with distilled water and weighed. Approximately $30 \mathrm{~g}$ of dried kernels were weighed, inserted into the pycnometer, and distilled water was added to fill the internal volume. The filled pycnometer was then weighed. Density $\left(\mathrm{g} / \mathrm{cm}^{3}\right)$ was calculated by dividing the weight of replaced water by the weight of corn kernels, assuming a water density of 1.0.

Corn vitreousness was determined by manual dissection of the kernels (Dombrink-Kurtzman and Bietz, 1993). The vitreousness of kernels varies depending on their position within the ear (Pratt et al., 1995). To minimize the effect of kernel position on the vitreousness measurement, 100 kernels from each maturity stage within hybrid were randomly selected and divided into 10 visually homogeneous groups based on kernel size and form. Vitreousness was then determined on one kernel randomly selected from each group. Kernels were soaked in distilled water for 3 minutes, dried with a paper towel, the pericarp and germ were removed with a scalpel, and the total endosperm was weighed. The floury endosperm was then manually removed using a scalpel, and the weight of the remaining vitreous endosperm was expressed as a percentage of the total endosperm.

Ruminal in situ degradations of corn kernel DM and starch were determined in three lactating Holstein cows fitted with ruminal cannulae. Cows were fed for ad libitum intake a diet (\% of DM) comprised of $29.4 \%$ corn silage, $29.4 \%$ alfalfa silage, and $41.2 \%$ shelled cornsoybean meal based concentrate. Cows were subjected to a 2 -wk adaptation period prior to the start of ruminal incubations. Corn kernels were dried at $60^{\circ} \mathrm{C}$ for $48 \mathrm{~h}$, ground through a Wiley mill (4 mm screen; Arthur H. Thomas, Philadelphia, PA), and approximately $5 \mathrm{~g}$ of the ground material was weighed into $9-\times 18$-cm nylon bags. Ruminal incubation times were 3, 6, 12, 24, and $48 \mathrm{~h}$. Bags were introduced into the rumen at staggered times for removal of all bags at the same time. Immediately after removal from the rumen, bags were washed in a washing machine (Cherney et al., 1990), and dried as described previously. Zero-hour bags were washed with the incubated bags during the same washing machine cycle, and used to estimate the instantaneously degradable A fraction. The residue of DM and starch (Bal et al., 2000b) was determined for each incubation time within each cow. In situ degradation parameters for DM and starch were estimated using the nonlinear model procedure of multivariate secant or false position (DUD) method in SAS (1985). The model used for describing kinetics of kernel DM and starch degradation was a simple first-order kinetic equation with an indigestible fraction. The ruminal availability of DM and starch were calculated assuming a fractional passage rate of 0.08/h (NRC, 2001).

Three U.S. dent hybrids (Jung 2240, Jung Seed Co., Randolph, WI; Lemke 3090, Lemke Seed Farms, Mequon, WI; Kaltenberg K7001, Kaltenberg Seed Co., Waunakee, WI) at the MT stage of maturity and three Brazilian flint hybrids (Zeneca Z8452, Sementes Dow Agrosciences, Jardinópolis, Brazil; Agroceres AG1051, Sementes Agroceres, Uberlândia, Brazil; Novartis Tork, Syngenta Seeds, Uberlândia, Brazil) were selected to represent the lowest, mid-point, and highest vitreous hybrids from each country for ruminal in situ incubations. Vitreousness values for the three U.S. hybrids were $34.9,43.7$, and $62.3 \%$, while vitreousness values for the Brazilian hybrids were 64.2, 75.5, and $80.0 \%$. Ruminal in situ degradation of two U.S. hybrids, the one with least (36.3\%; Pfister 2025, Pfister, El Paso, IL) and the one with greatest $(55.2 \%$; Novartis N2555Bt, NK Brand, Basel, Switzerland) average kernel vitreousness, was evaluated at the three maturity stages. 
Stage of maturity effects within the 14 U.S. dent hybrids on kernel DM and starch contents, vitreousness, and density were analyzed using the GLM procedure of SAS (1985), with hybrid as the experimental unit. Statistical relationships (density with vitreousness, maturity with vitreousness, maturity with density, vitreousness with ruminal in situ degradation, and density with ruminal in situ degradation) were determined by regression in SAS (1985).

\section{RESULTS AND DISCUSSION}

Vitreousness of the five Brazilian flint hybrids at MT averaged $73.1 \%$ (a range of $64.2 \%$ to $80.0 \%$ ), while vitreousness of the 14 U.S. dent hybrids at MT averaged $48.2 \%$ (a range of $34.9 \%$ to $62.3 \%$ ). Philippeau and Michalet-Doreau (1997), studying flint and dent cultivars at different stages of growth, found that vitreousness at the mature stage of growth was $72.3 \%$ for flint and $48.1 \%$ for dent hybrids. In another study, vitreousness was $71.8 \%$ for flint and $51.4 \%$ for dent hybrids (Philippeau et al., 2000). Based on vitreousness, our Brazilian flint and U.S. dent hybrids were representative of corn studied in these European trials.

Density of the five Brazilian flint hybrids at MT averaged $1.268 \mathrm{~g} / \mathrm{cm}^{3}$ (a range of 1.218 to $1.292 \mathrm{~g} / \mathrm{cm}^{3}$ ), while density of the 14 U.S. dent hybrids at MT averaged $1.201 \mathrm{~g} / \mathrm{cm}^{3}$ (a range of 1.169 to $1.235 \mathrm{~g} / \mathrm{cm}^{3}$ ). Kernels from commercial Brazilian flint hybrids had greater vitreousness and density than commercial dent hybrids from Midwest U.S.

Kernel hardness is an index of the relative proportion of vitreous to floury endosperm. The direct laboratory measurement of vitreousness is labor intensive, while determining grain density with a picnometer is less so. Since hardness is the major factor determining density (Bergquist and Thompson, 1992), density may be a good indirect measure of vitreousness (Philippeau et al., 1999). The correlation between density and vitreousness was $0.87(P<0.001)$ (Figure 1$)$, which suggests that density may be a reliable tool for screening large corn data sets for vitreousness.

For the 14 U.S. dent hybrids, days from planting to harvest was $139 \pm 4.5$ (mean \pm SD) d at HM, $155 \pm 5.3$ $\mathrm{d}$ at $\mathrm{BL}$, and $176 \pm 5.8 \mathrm{~d}$ at MT (Figure 2 ). Within each maturity stage, the highest vitreousness measurements were on the earlier maturing (fewer days from planting to harvest) hybrids. Days from $50 \%$-silking to HM was $51 \mathrm{~d}$, to BL was $67 \mathrm{~d}$, and to MT was $88 \mathrm{~d}$.. Vitreousness had a greater correlation with days from planting to MT ( $\mathrm{r}=-0.77 ; P<0.001)$ than with days from 50\%-silking to MT $(\mathrm{r}=-0.63 ; P<0.001)$.

Within the U.S. dent hybrids, kernel DM, vitreousness, and density increased $(P<0.001)$ with advancing

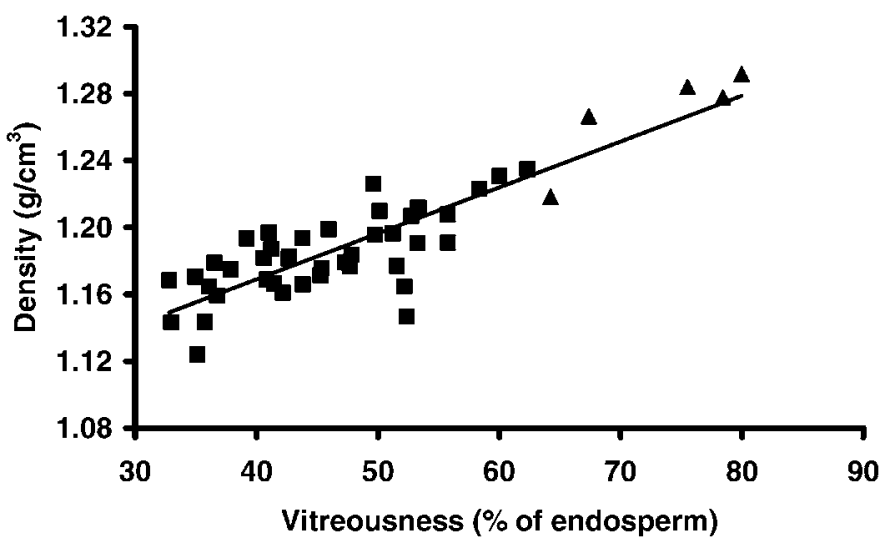

Figure 1. Relationship between corn kernel vitreousness and density determined on fourteen U.S. dent hybrids at three maturity stages ( $\mathbf{\square})$ and five mature Brazilian flint hybrids $(\boldsymbol{\Delta})$. Vitreousness $=-283.2+278.2 *$ Density; $\mathrm{r}^{2}=0.76 . P<0.001$.

maturity (Table 1). The increase in grain density was larger from BL to MT than from HM to BL, thus showing a different response to advancing maturity than observed for vitreousness. Philippeau and MichaletDoureau (1997) reported that vitreousness of a dent corn hybrid increased with advancing maturity. Stage of maturity did not influence the starch content of the U.S. dent hybrids. Doehlert et al. (1994) observed a marked linear increase in grain DM content between 15 and $40 \mathrm{~d}$ after pollination, while after that period kernels lost moisture at a slower rate and kernel fill ceased by the time whole grain moisture content dropped to about 37\%. Philippeau and Michalet-Doreau (1997) observed that kernel starch content did not increase after $34 \%$ and $37 \%$ kernel moisture content was

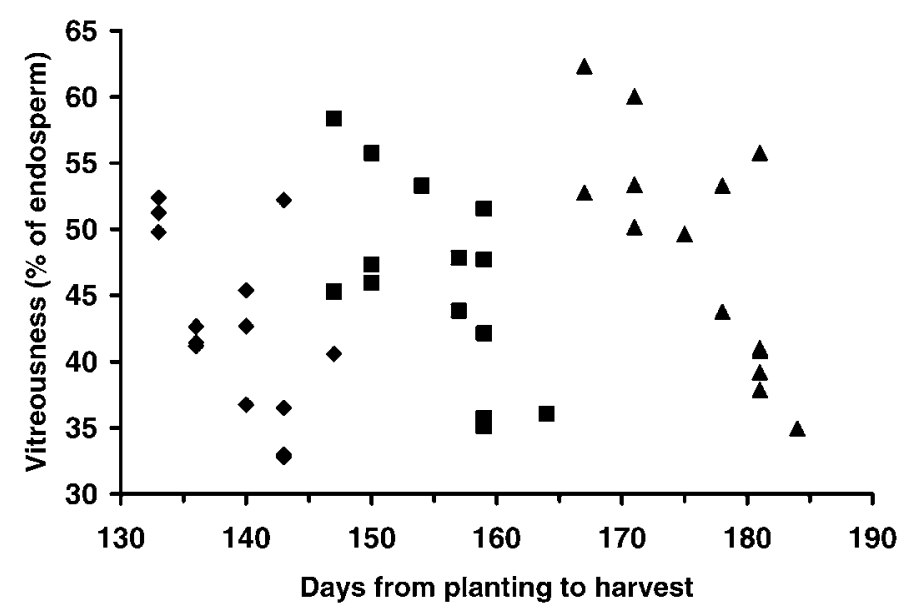

Figure 2. Relationship between corn kernel vitreousness and days from planting to harvest of fourteen U.S. dent hybrids at three maturity stages $($ Half milk line, $\boldsymbol{\square}$ Black layer, $\boldsymbol{\Delta}$ Mature). 
Table 1. Kernel dry matter, vitreousness, density, and starch content of kernels from fourteen U.S. dent corn hybrids harvested at onehalf milk line (HM), black layer (BL), and mature (MT) stages of maturity.

\begin{tabular}{llllll}
\hline & HM & BL & MT & SEM & $P<$ \\
\hline DM, \% & 62.0 & 74.3 & 87.1 & 0.6 & 0.001 \\
Vitreousness, \% & 42.8 & 46.1 & 48.2 & 1.0 & 0.001 \\
Density, g/cm $^{3}$ & 1.173 & 1.176 & 1.201 & 0.003 & 0.001 \\
Starch, \% of DM & 79.3 & 80.1 & 79.9 & 0.6 & 0.70 \\
\hline
\end{tabular}

reached in dent and flint corn, respectively. The first harvest was done $50.5 \pm 2.5 \mathrm{~d}$ after $50 \%$-silking and grain moisture was $38.0 \pm 1.2 \%$ (mean $\pm \mathrm{SD}$ ). We probably harvested our hybrids at maturity stages too advanced to observe an effect of maturity on kernel starch content.

The correlation between vitreousness and ruminal starch availability was $-0.93(P<0.001$; Figure $3 ; 12$ in situ comparisons). Philippeau and Michalet-Doureau (1997) observed a value of -0.86 for the same correlation. Vitreousness was correlated with the starch A fraction $(-0.91 ; P<0.001)$ and the fractional rate of starch degradation $(-0.66 ; P<0.001)$. Density was correlated with ruminal starch availability $(-0.87 ; P<$ 0.001; Figure 4; 12 in situ comparisons), which suggests that density may be a reliable predictor of not only vitreousness but also ruminal starch availability. The correlation between ruminal starch and DM availability was $0.98(P<0.001)$. Ruminal DM degradation seems to be an accurate predictor of ruminal starch

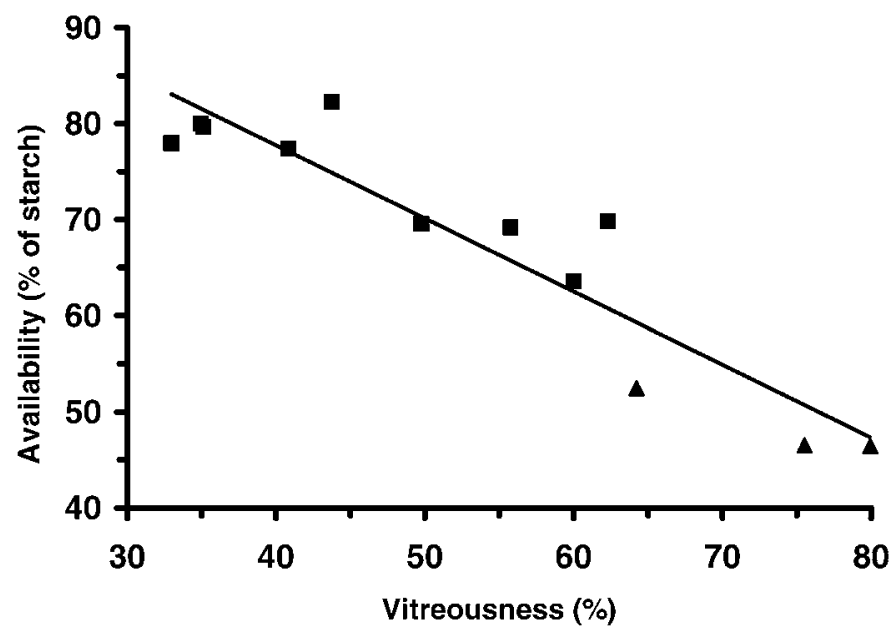

Figure 3. Relationship between corn kernel vitreousness and ruminal in situ starch availability measured in three U.S. dent (ם) and three Brazilian flint $(\boldsymbol{\Delta})$ hybrids harvested at the mature stage of maturity and two U.S. dent ( $)$ hybrids harvested at half milk line, black layer, and mature stages of maturity. Availability $=\mathrm{A}+\mathrm{B}\left[\mathrm{k}_{\mathrm{d}}\right]$ $\left.\left(\mathrm{k}_{\mathrm{d}}+\mathrm{k}_{\mathrm{p}}\right)\right]$ with $\mathrm{K}_{\mathrm{p}}$ at $0.08 / \mathrm{h}$. Availability $=108.2-0.7605 *$ Vitreousness. $\mathrm{r}^{2}=0.87 . P<0.001$.

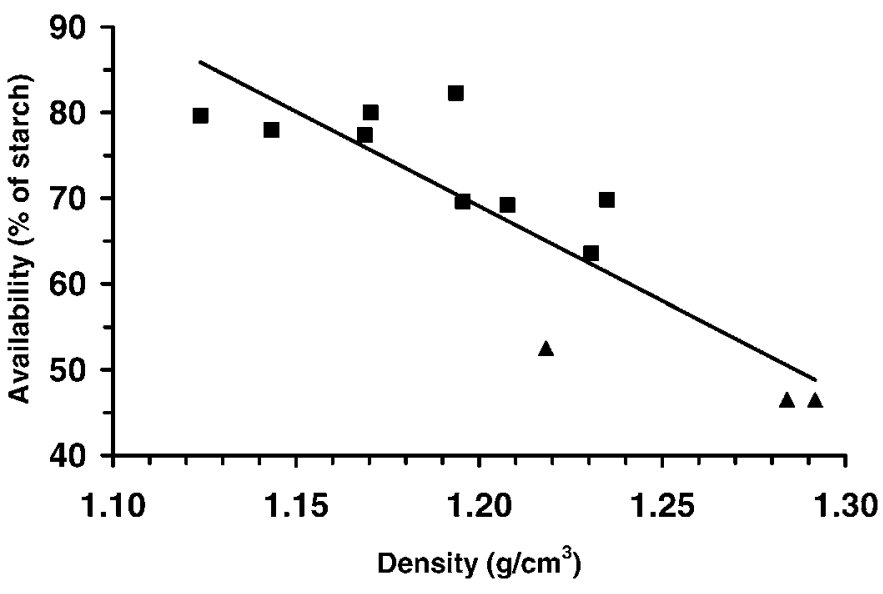

Figure 4. Relationship between corn kernel density and ruminal in situ starch availability measured in three U.S. dent (ם) and three Brazilian flint ( $\mathbf{\Delta})$ hybrids harvested at the mature stage of maturity and two U.S. dent ( $)$ hybrids harvested at half milk line, black layer, and mature stages of maturity. Availability $=\mathrm{A}+\mathrm{B}\left[\mathrm{k}_{\mathrm{d}} /\left(\mathrm{k}_{\mathrm{d}}+\mathrm{k}_{\mathrm{p}}\right)\right]$ with $\mathrm{K}_{\mathrm{p}}$ at $0.08 / \mathrm{h}$. Availability $=333.96-220.75$ Density. $\mathrm{r}^{2}=0.75 . P$ $<0.001$.

degradation for corn kernels, which would reduce the cost associated with starch analysis of in situ bag residues.

The mean vitreousness across maturity stages for the high vitreousness U.S. dent hybrid (HVH) was $55.2 \%$ of the endosperm; $49.8 \%$ at HM, $55.8 \%$ at BL, and $60.0 \%$ at MT. For the low vitreousness U.S. dent hybrid (LVH), the mean value was $36.3 \%$; 33.0\% at HM, 35.1\% at BL, and $40.8 \%$ at MT. Kernel DM content for $\mathrm{HVH}$ was $63.2 \%$ at HM, $69.8 \%$ at BL, and $84.7 \%$ at MT. For $\mathrm{LVH}$, kernel DM content was $62.8 \%$ at $\mathrm{HM}, 75.7 \%$ at $\mathrm{BL}$, and $87.9 \%$ at MT. Previous research on kernel vitreousness usually compared flint corn with dent corn, and found a negative impact of increased kernel vitreousness on ruminal starch degradation (Philippeau and Michalet-Doureau, 1997; Philippeau et al., 1999). We compared two dent corn hybrids differing in kernel vitreousness and found greater ruminal starch availability for LVH (Figure 5; six in situ comparisons). These data suggest that, in dent corn populations, vitreousness may be a useful parameter to select corn hybrids for high ruminal starch availability.

Ruminal starch availability showed a decline after the BL stage of maturity and this decline was more accentuated for $\mathrm{HVH}$ than LVH (Figure 5; quadratic regression $\mathrm{r}^{2}=0.69 \mathrm{HVH}$ vs. 0.15 for LVH), suggesting that ruminal availability of higher vitreousness kernels may be more affected by advancing of maturity. Bal et al. (1997) observed a decrease in total-tract starch digestibility in dairy cows when harvest of corn silage was delayed from $2 / 3$ milk line to BL. Calestine et al. (2001) observed that corn grain cut into four pieces, to 


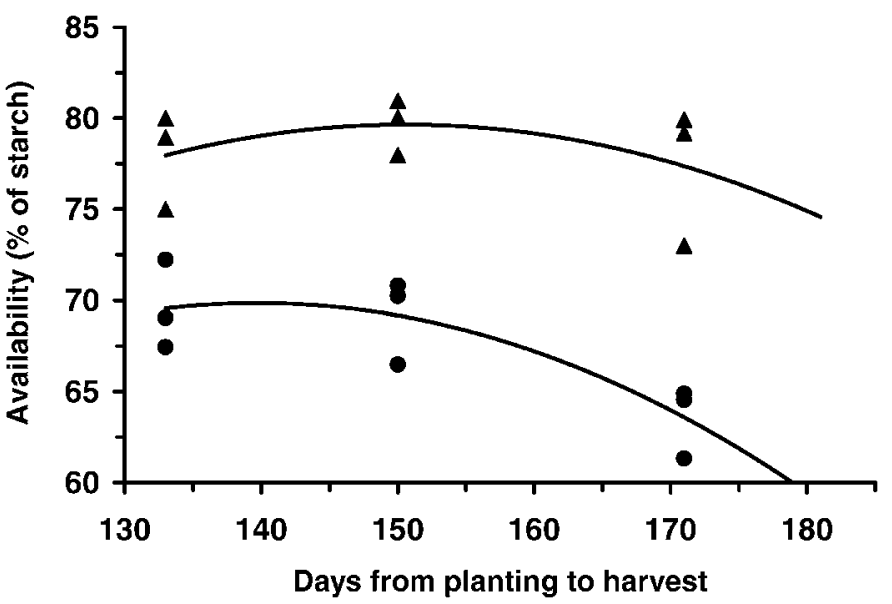

Figure 5. Relationship between ruminal starch availability and days from planting to harvest (X) of low (LVH; $\mathbf{\Delta})$ and high $(\mathrm{HVH}$; -) vitreousness U.S. dent hybrids. Availability $=\mathrm{A}+\mathrm{B}\left[\mathrm{k}_{\mathrm{d}} /\left(\mathrm{k}_{\mathrm{d}}+\mathrm{k}_{\mathrm{p}}\right)\right]$ with $\mathrm{K}_{\mathrm{p}}$ at $0.08 / \mathrm{h}$. Availabilty $=-44.639+1.6511 \mathrm{X}-0.0055 \mathrm{X}^{2}, \mathrm{r}^{2}=$ $0.15(P<0.001)$ for LVH and Availability $=-55.086+1.7886-0.0064$ $\mathrm{X}^{2}, \mathrm{r}^{2}=0.69(P<0.001)$ for $\mathrm{HVH}$.

simulate silage processing, showed a marked decline in ruminal degradability with advancing maturity from $\mathrm{HM}$ to BL. In this experiment, corn samples were ground through a $4 \mathrm{~mm}$ Wiley screen, which may have lowered the sensitivity of the in situ assay to detect differences in degradation between HM and BL. Corn hybrids of high vitreousness may have a greater decrease in starch digestibility in response to delayed harvest than hybrids with low vitreousness (Johnson et al., 2002).

\section{CONCLUSIONS}

With advancing maturity in dent corn hybrids, kernel vitreousness and density increased while ruminal starch availability decreased. The decrease in ruminal starch availability with advancing maturity within dent corn was greater for the most vitreous hybrid. Kernel vitreousness may be a useful parameter for which to select corn hybrids for high ruminal starch availability. Measurement of kernel density is less labor intensive than the vitreousness determination, and density appears to be a reliable predictor of vitreousness and ruminal starch availability.

\section{REFERENCES}

Bal, M. A., J. G. Coors, and R. D. Shaver. 1997. Impact of the maturity of corn for use as silage in the diets of dairy cows on intake, digestion, and milk production. J. Dairy Sci. 80:2497-2503.

Bal, M. A., R. D. Shaver, H. Al-Jobeile, J. G. Coors, and J. G. Lauer. 2000a. Corn silage hybrid effects on intake, digestion, and milk production by dairy cows. J. Dairy Sci. 83:2849-2858.

Bal, M. A., R. D. Shaver, A. G. Jirovec, K. J. Shinners, and J. G. Coors. 2000b. Crop processing and chop length of corn silage: Effects on intake, digestion, and milk production by dairy cows. J. Dairy Sci. 83:1264.

Bal, M. A., R. D. Shaver, K. J. Shinners, J. G. Coors, J. G. Lauer, R. J. Straub, and R. G. Koegel. 2000c. Stage of maturity, processing, and hybrid effects on ruminal in situ disappearance of wholeplant corn silage. Anim. Feed Sci. Technol. 86:83-94.

Bergquist, R. R., and D. L. Thompson. 1992. Corn grain density characterized by two specific gravity techniques. Crop Sci. 32:1287-1290.

Calestine, G. A., M. N. Pereira, R. G. S. Bruno, R. G. Von Pinho, and C. E. S. Correa. 2001. Effect of corn grain texture and maturity on ruminal in situ degradation. J. Dairy Sci. 84(Suppl.1):419(Abstr.).

Cherney, D. J. R., J. A. Patterson, and R. P. Lemenager. 1990. Influence of in situ bag rinsing technique on determination of dry matter disappearence. J. Dairy Sci. 73:391-397.

Dhiman, T. R., M. A. Bal, Z. Wu, V. R. Moreira, R. D. Shaver, L. D. Satter, K. J. Shinners, and R. P. Walgenbach. 2000. Influence of mechanical processing on utilization of corn silage by lactating dairy cows. J. Dairy Sci. 83:2521-2528.

Doehlert, D. C., L. J. Smith, and E. R. Duke. 1994. Gene expression during maize kernel development. Seed Sci. Res. 4:299-305.

Dombrink-Kurtzman, M. A., and J. A. Bietz. 1993. Zein composition in hard and soft endosperm of maize. Cereal Chem. 70:105-108.

Johnson, L. M., J. H. Harrison, D. Davidson, J. L. Robutti, M. Swift, W. C. Mahanna, and K. Shinners. 2002. Corn silage management I: Effects of hybrid, maturity, and mechanical processing on chemical and physical characteristics. J. Dairy Sci. 85:833-853.

National Research Council. 2001. Nutrient Requirements of Dairy Cattle. 7th ed. Natl. Acad. Sci., Washington, DC.

Philippeau, C., J. Landry, and B. Michalet-Doreau. 2000. Influence of the protein distribution of maize endosperm on ruminal starch degradability. J. Sci. Food Agric. 80:404-408.

Philippeau, C., F. Le Deschault de Monredon, and B. Michalet-Doreau. 1999. Relationship between ruminal starch degradation and the physical characteristics of corn grain. J. Anim. Sci. 77:238243.

Philippeau, C., and B. Michalet-Doreau. 1997. Influence of genotype and stage of maturity of maize on rate of ruminal starch degradation. Anim. Feed Sci. Technol. 68:25-35.

Pratt, R. C., J. W. Paulis, K. Miller, T. Nelsen, and J. A. Bietz. 1995. Association of zein classes with maize kernel hardness. Cereal Chem. 72:162-167.

SAS User's Guide: Statistics, Version 5 Edition. 1985. SAS Institute Inc., Cary, NC. 